\title{
Are Sitting Position and Working Duration Associated with Low Back Pain in Workers?: A Meta-Analysis
}

\author{
Herawati Prianggi'), Bhisma Murti'), Hanung Prasetya ${ }^{2)}$ \\ 1)Masters Program in Public Health, Universitas Sebelas Maret \\ ${ }^{2}$ Health Polytechnics, Ministry of Health Surakarta
}

\section{ABSTRACT}

Background: Low back pain (LBP) is generally suffered by adults due to the position of the activity while working continuously. LBP can have an impact on an individual's quality of life because it can cause pain and impaired body/ movement functions. This study aims to systematically and quantitatively synthesized the relationships of sitting posture position, working duration, and low back pain in workers.

Subjects and Method: A systematic review and meta-analysis was conducted by collecting articles from a number of databases such as PubMed, Science Direct, and Google Scholar. The keywords used in the article search were "Low Back Pain" AND "Low Back Pain" AND "Office Employees" "work attitude", "work attitude" AND "years of service OR "Low Back Pain" Low Back Pain OR work attitude" "years of service" OR "work attitude" "Work attitude AND Low Back Pain OR Low Back Pain AND "year of service "Low Back Pain" AND "adjusted odds ratio" "Years of service" AND "adjusted odds ratio "Pathophysiology Low Back Pain". Articles were collected and selected using the PICO model, including: (1) Population = office workers, (2) Intervention = sitting position and length of service, (3) Comparison= without intervention, and (4) Outcome = low back pain. Inclusion criteria in this study is full-text, the article uses an observational study design, the article is published from 2004 to 2021, the research population is workers, reports the Adjusted Odd Ratio (AOR). The articles that have been collected are selected using the PRISMA diagram. The qualitative synthesis of research data was tested using the Review Manager application (RevMan 5.3).

Results: Meta-analysis of 9 cross-sectional studies showed that workers who worked 5 years had a risk of experiencing low back pain 1.43 times compared to $<5$ years $(\mathrm{aOR}=1.87$; $95 \% \mathrm{CI}=1.43$ to $0.95 ; \mathrm{p}=0.08$ ). Meta-analysis of 7 cross-sectional studies showed that workers who sat for 8 hours had a risk of experiencing low back pain 1.31 times compared to $<8$ hours $(\mathrm{aOR}=1.31 ; 95 \% \mathrm{CI}=0.64$ to $2.54, \mathrm{p}=$ $0.43)$.

Conclusion: Length of work 5 years and sitting position 8 hours increase the risk of experiencing low back pain in office employees.

Keywords: low back pain, sitting position, working period, office worker

\section{Correspondence:}

Herawati Prianggi. Masters Program in Public Health, Universitas Sebelas Maret. Jl. Ir. Sutami 36A, Surakarta 57126, Central Java. Email: herawatiprianggii@gmail.com. Mobile: o89670447344.

Cite this as:

Prianggi H, Murti B, Prasetya H (2021). Are Sitting Position and Working Duration Associated with Low Back Pain in Office Workers?: A Meta-Analysis. J Epidemiol Public Health. 06(02): 211-221. https://doi.org/10.26911/jepublichealth.2021.06.02.08.

cc (i) (8) Journal of Maternal and Child Health is licensed under a Creative Commons EY NC SA Attribution-NonCommercial-ShareAlike 4.0 International License.

\section{BACKGROUND}

Risk factors that can cause low back pain in a worker, namely gender, age, mass index, years of service and length of work on a worker, attitude, and standing position
(Chaman, 2015).

Complaints of low back pain can also occur due to work activities. Research conducted in Turkey (2014) reported that $48.3 \%$ of workers experienced mild pain, 
24.8\% experienced moderate pain, and $10.3 \%$ experienced severe pain. As many as $62.1 \%$ of these workers experience low back pain after working with the same body position continuously (Farnam, 2016).

Meta-analysis is an epidemiological design that aims to systematically examine and combine quantitative estimation results from a number of previous studies that answer the same research problem and can be combined. Many primary studies have investigated the effect of work attitude and tenure on low back pain. Further analysis is needed to reach convincing conclusions. Based on this background, researchers are interested in conducting a systematic review and meta-analysis on "the influence of work attitudes and tenure on Low Back Pain".

\section{SUBJECTS AND METHOD}

\section{Study Design}

This study is a systematic review and metaanalysis. The articles used in this study were obtained from several electronic databases of research journals, including: PubMed, Science Direct, and Google Scholar. The keywords used in the article search were: "Low Back Pain" AND "Low Back Pain" AND "Office Employees" "work attitude", "work attitude" AND "years of service OR "Low Back Pain" Low Back Pain OR work attitude" "years of service" OR “ work attitude" "Work attitude AND Low Back Pain OR Low Back Pain AND "year of service "Low Back Pain" AND "adjusted odds ratio" "Years of service" AND "adjusted odds ratio " Pathophysiology Low Back Pain".

\section{Inclusion Criteria}

The inclusion criteria in this study were full-text, articles using an observational study design, articles published from 2007 to 2021, the study population was office workers, reporting Adjusted Odd Ratio (AOR).

\section{Operational Definition of Variables}

The search for articles was carried out by considering the eligibility criteria defined using the PICO model, including: (1) Population $=$ workers, (2) Intervention $=$ sitting position and work duration, (3) Comparison $=$ without intervention, and (4) Outcome $=$ low back pain.

Low back pain is pain that is felt in the lower back area between the angle of the lower ribs to the sacrum.

Term of service is the period of time an employee works at a workplace.

Sitting position is the position spent by office employees when doing work.

\section{Data Analysis}

Data processing is carried out using the Review Manager (RevMan 5.3) by calculating the Adjusted odds ratio (aOR) on eligible research articles and forming the final results of the meta-analysis.

\section{RESULTS}

The process of searching and selecting articles in this meta-analysis can be seen in Figure 1. 9 articles were obtained for quantitative synthesis of the relationship between tenure and low back pain, which came from studies in Australia, Asia, Europe, and America. An overview of the research area can be seen in Figure 2.

\section{The relationship between work duration and low back pain}

There are 7 cross-sectional research articles that meet the inclusion criteria for a metaanalysis of the relationship between work duration and low back pain in office employees. Table 1 shows the identification of critical appraisal of the selected articles for quantitative synthesis. 
Prianggi et al./ Sitting Position, Working Duration, and Low Back Pain

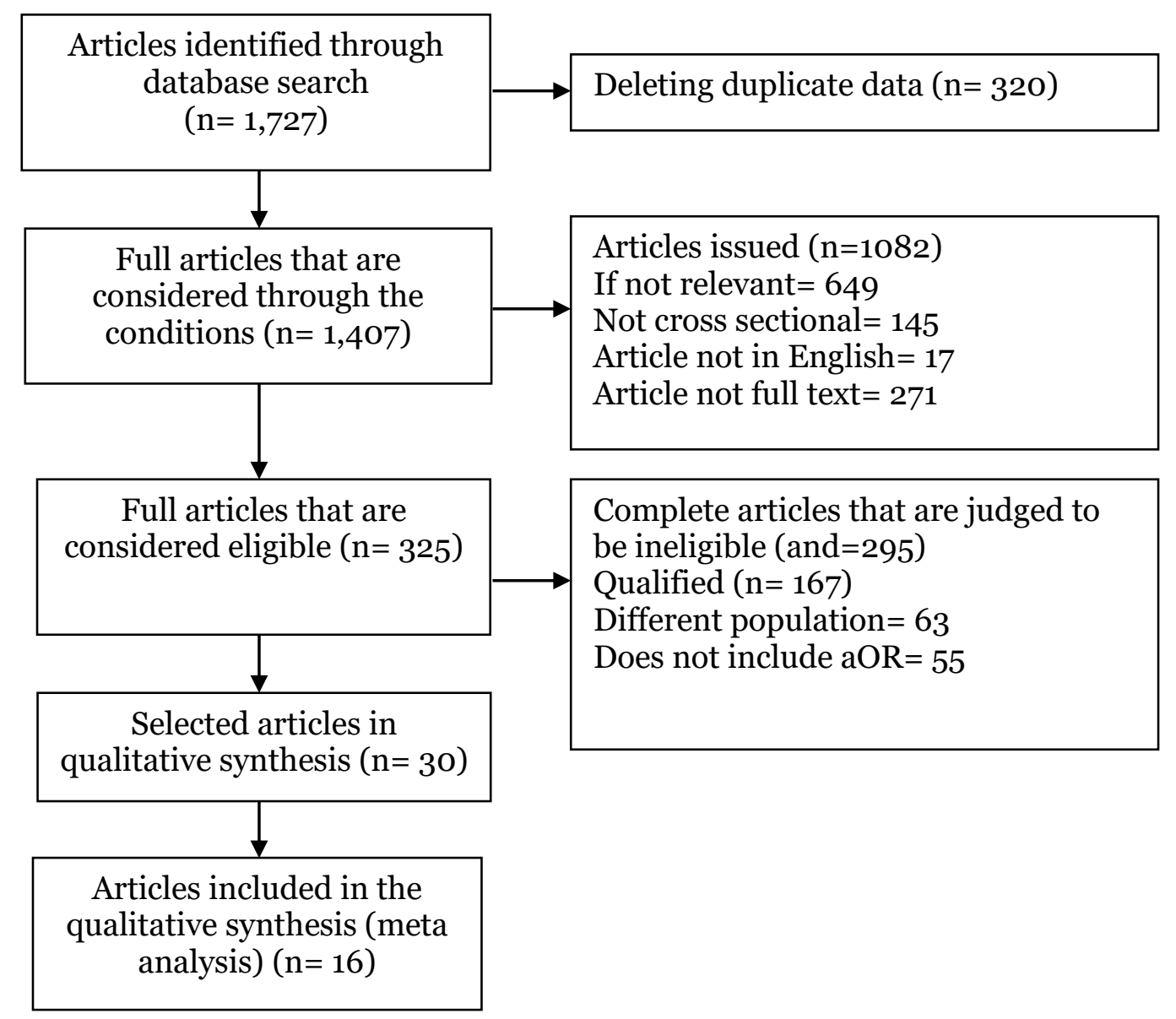

Figure 1. PRISMA diagram of the process of collecting and selecting research articles

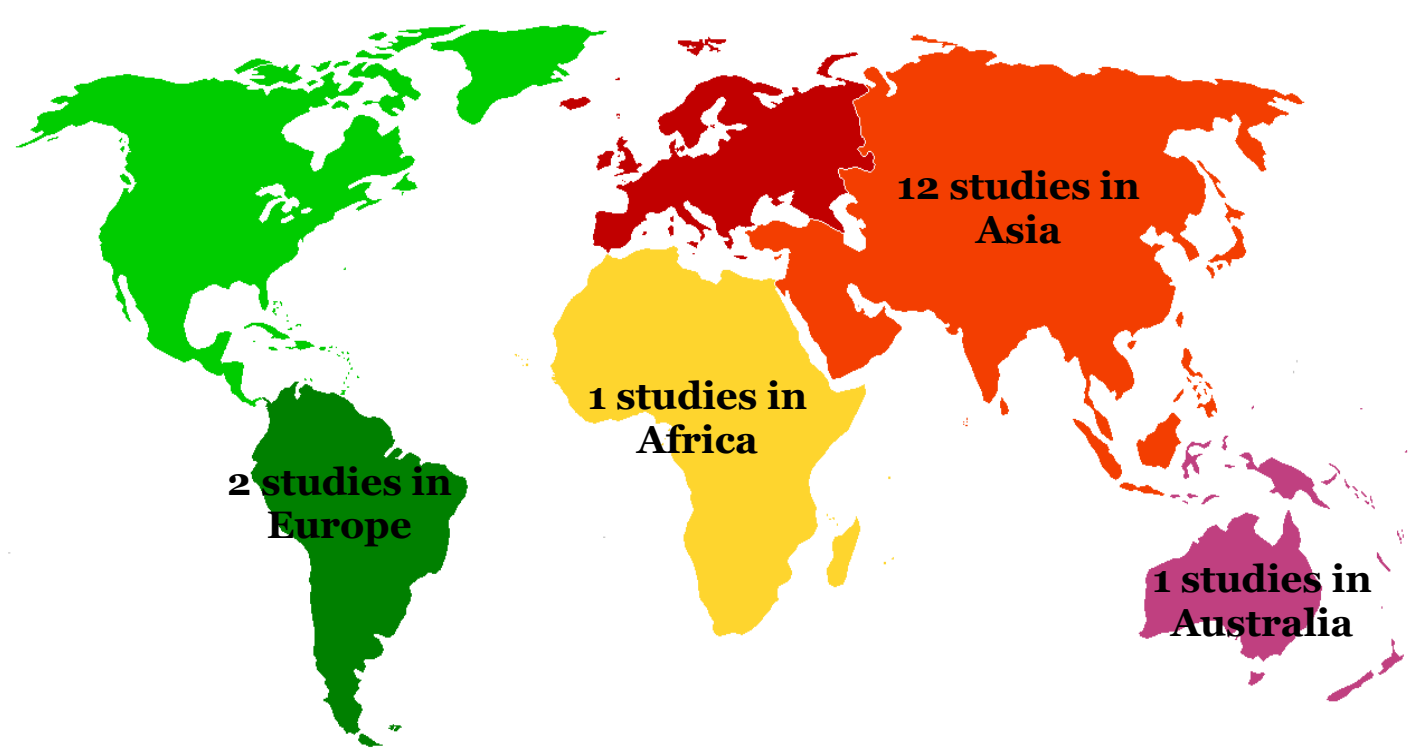

Figure 2. Overview of the research area 
Prianggi et al./ Sitting Position, Working Duration, and Low Back Pain

a. Forest plot

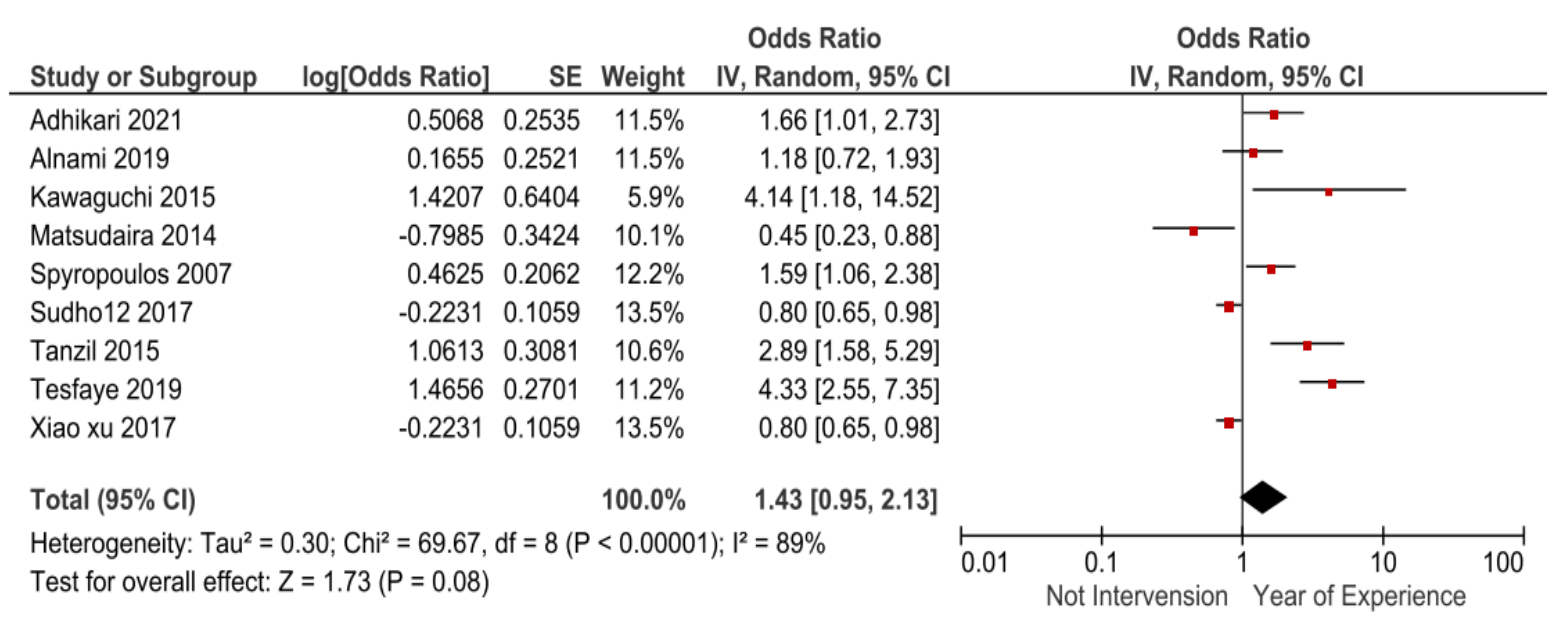

Figure 2. Forest plot of the relationship between work duration and low back pain

The forest plot in Figure 2 shows that there is an effect of length of service on the risk of office employees to experience low back pain, and the effect is statistically signifyb. Funnel Plot cant. Office employees who worked 5 years had a risk of experiencing low back pain 1.43 times compared to $<5$ years $(\mathrm{aOR}=$ $1.43 ; 95 \% \mathrm{CI}=0.95$ to $2.13 ; \mathrm{p}=0.001$ ).

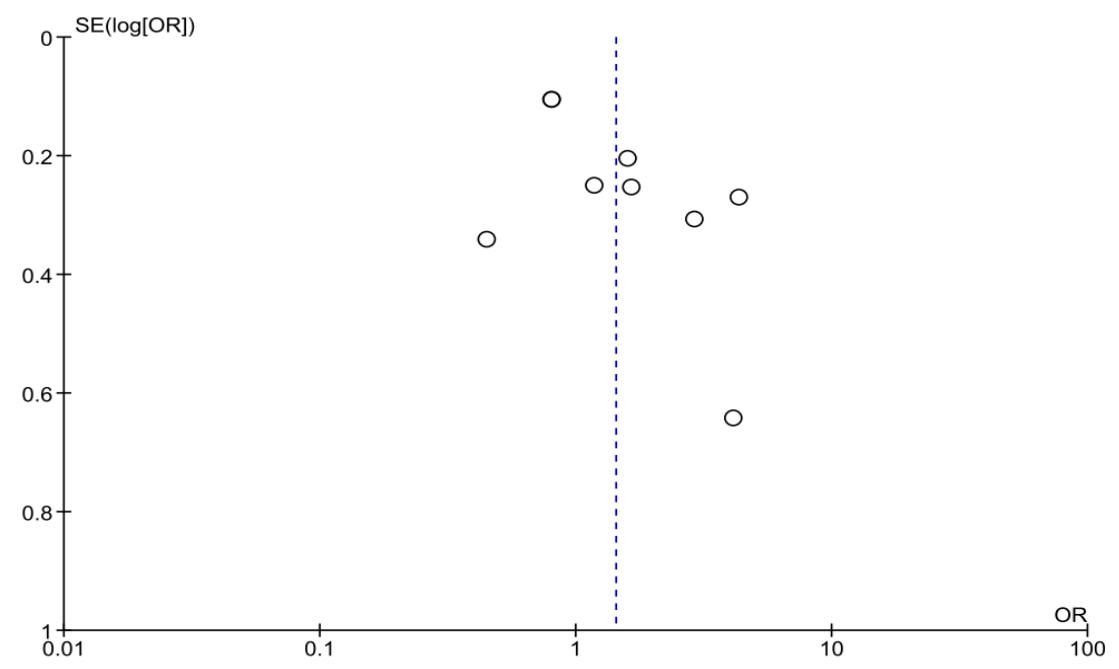

Figure 3. Funnel plot of the relationship between work duration and low back pain

The funnel plot in Figure 3 shows an asymmetric distribution of the estimated primary study results, weight to the left of the vertical line, which indicates that there is publication bias that overestimates the true effect (underestimate).

\section{The relationship between sitting position and low back pain}

There are 7 primary articles with crosssectional research as a reference source for meta-analysis of the relationship between sitting position at work and low back pain 
Prianggi et al./ Sitting Position, Working Duration, and Low Back Pain

in office employees. The identification of

each article can be seen in Table 2.

\section{a. Forest Plot}

Odds Ratio Odds Ratio

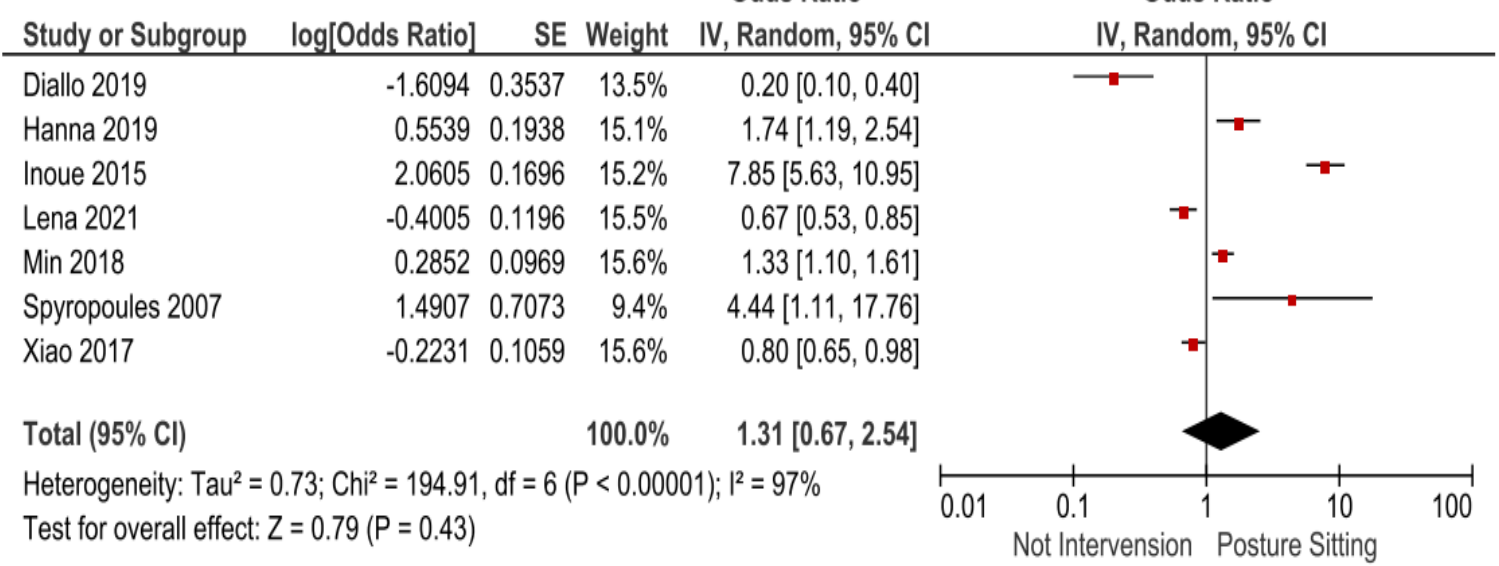

Figure 4. Forest plot of the relationship between sitting position and low back pain

The forest plot in Figure 4 shows that there is an effect of working attitude in a long sitting position on the risk of office employees to experience low back pain, and the effect is not statistically significant. Office b. Funnel Plot

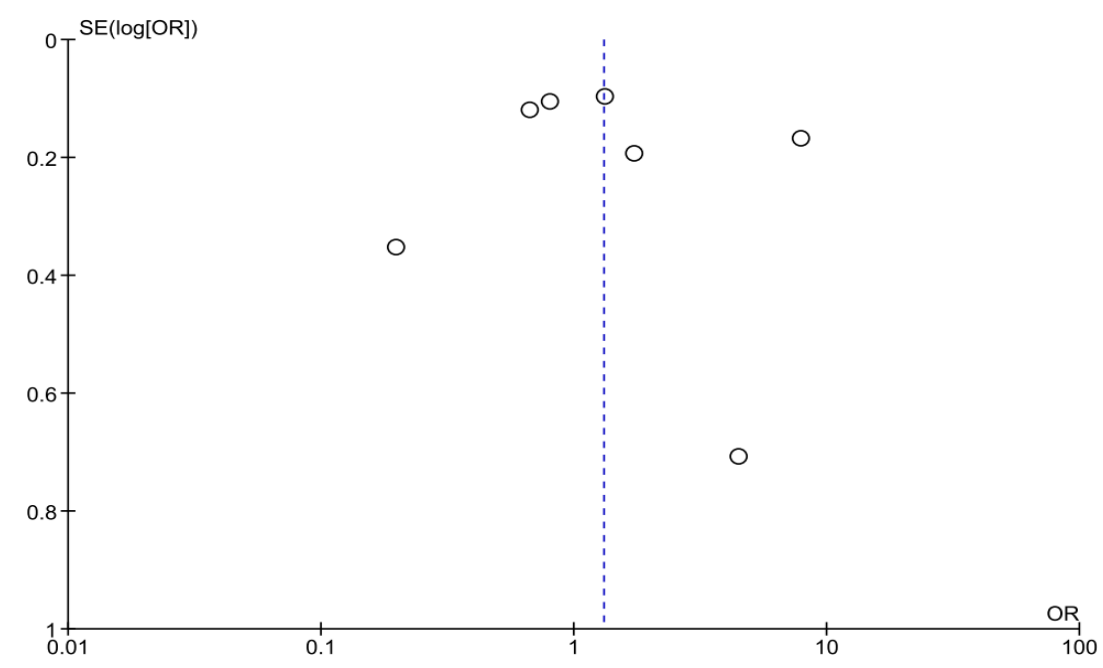

\section{Figure 5. Funnel Plot of the relationship between sitting position} attitude and low back pain

The funnel plot in Figure 5 shows a symmetrical distribution of the estimated results of the primary study, the right plot is four and the left plot is four, while there is one employees who sat for $\geq 8$ hours had a risk of experiencing low back pain 1.31 times compared to $<8$ hours $(\mathrm{aOR}=1.31 ; 95 \% \mathrm{CI}=$ 0.67 to $2.54, \mathrm{p}=0.43)$. 
Table 1. Critical appraisal of articles on the relationship between tenure and low back pain

\begin{tabular}{|c|c|c|c|c|c|c|c|c|c|c|}
\hline No & Questions of Checklist & $\begin{array}{l}\text { Adhikari et } \\
\text { al (2021) }\end{array}$ & $\begin{array}{c}\text { Alnami } \\
\text { et al } \\
\text { et al } \\
(2019)\end{array}$ & $\begin{array}{c}\text { Kawaguc } \\
\text { hi } \\
\text { et al } \\
(2017) \\
\end{array}$ & $\begin{array}{c}\text { Matsu- } \\
\text { daira } \\
\text { et al } \\
\text { (2014) }\end{array}$ & $\begin{array}{c}\text { Spyo- } \\
\text { poulos } \\
\text { et al } \\
(2007) \\
\end{array}$ & $\begin{array}{c}\text { Sudholz } \\
\text { et al } \\
(2017)\end{array}$ & $\begin{array}{c}\text { Tanzil } \\
\text { et al } \\
(2015)\end{array}$ & $\begin{array}{c}\text { Tesfaye } \\
\text { et al } \\
(2019)\end{array}$ & $\begin{array}{c}\text { Xioxu } \\
\text { et al } \\
(2017)\end{array}$ \\
\hline 1 & $\begin{array}{l}\text { Does this research address clearly focused } \\
\text { issues }\end{array}$ & 1 & 1 & 1 & 1 & 1 & 1 & 1 & 1 & 1 \\
\hline 2 & $\begin{array}{l}\text { Is the cross-sectional research method } \\
\text { appropriate to answer the research question? }\end{array}$ & 1 & 1 & 1 & 1 & 1 & 1 & 1 & 1 & 1 \\
\hline 3 & $\begin{array}{l}\text { Are there enough subjects to establish that } \\
\text { the findings did not occur by chance? }\end{array}$ & 1 & 1 & 1 & 1 & 1 & 1 & 1 & 1 & 1 \\
\hline 4 & $\begin{array}{l}\text { Was the cross-sectional selection based on } \\
\text { objective and validated criteria? }\end{array}$ & 1 & 1 & 1 & 1 & 1 & 1 & 1 & 1 & 1 \\
\hline 5 & $\begin{array}{l}\text { Is the cross-sectional representative of the } \\
\text { defined population? }\end{array}$ & 1 & 1 & 1 & 1 & 1 & 1 & 1 & 1 & 1 \\
\hline 6 & Was the follow-up done in sufficient time? & 1 & 1 & 1 & 1 & 1 & 1 & 1 & 1 & 1 \\
\hline 7 & $\begin{array}{l}\text { Are objective and unbiased outcome criteria } \\
\text { used? }\end{array}$ & 1 & 1 & 1 & 1 & 1 & 1 & 1 & 1 & 1 \\
\hline 8 & $\begin{array}{l}\text { What is a low back pain intervention } \\
\text { measurement method? }\end{array}$ & O & 0 & $\mathrm{O}$ & o & O & o & $\mathrm{O}$ & o & O \\
\hline 9 & Are effect sizes practically relevant? & 1 & 1 & 1 & 1 & 1 & 1 & 1 & 1 & 1 \\
\hline 10 & Is there a belief intervention provided? & 1 & 1 & 1 & 1 & 1 & 1 & 1 & 1 & 1 \\
\hline 11 & $\begin{array}{l}\text { Have confounding factors been taken into } \\
\text { account? }\end{array}$ & 1 & 1 & 1 & 1 & 1 & 1 & 1 & 1 & 1 \\
\hline \multirow[t]{2}{*}{12} & Do the results apply to your research? & 1 & 1 & 1 & 1 & 1 & 1 & 1 & 1 & 1 \\
\hline & Total & 11 & 11 & 11 & 11 & 11 & 11 & 11 & 11 & 11 \\
\hline
\end{tabular}

Answer: 1 Yes $0=$ No 
Table 2. Critical appraisal of articles on the relationship between sitting position and low back pain

\begin{tabular}{|c|c|c|c|c|c|c|c|c|}
\hline No & Questions of Checklist & $\begin{array}{l}\text { Diallo et } \\
\text { al (2019) }\end{array}$ & $\begin{array}{l}\text { Hanna et al } \\
\quad(2019)\end{array}$ & $\begin{array}{l}\text { Inoue et } \\
\text { al (2015) }\end{array}$ & $\begin{array}{l}\text { Lena et al } \\
(2021)\end{array}$ & $\begin{array}{l}\text { Min et al } \\
(\mathbf{2 0 1 8})\end{array}$ & $\begin{array}{c}\text { Spyro- } \\
\text { poules et al } \\
(2007)\end{array}$ & $\begin{array}{l}\text { Xio et al } \\
(2017)\end{array}$ \\
\hline 1 & $\begin{array}{l}\text { Does the research address a clearly focused } \\
\text { problem? }\end{array}$ & 1 & 1 & 1 & 1 & 1 & 1 & 1 \\
\hline 2 & Is the research method cross-sectional? & 1 & 1 & 1 & 1 & 1 & 1 & 1 \\
\hline 3 & $\begin{array}{l}\text { Are there enough subjects to establish that the } \\
\text { findings did not occur by chance? }\end{array}$ & 1 & 1 & 1 & 1 & 1 & 1 & 1 \\
\hline 4 & $\begin{array}{l}\text { Did you choose cross-sectional based on } \\
\text { objective and validated criteria? }\end{array}$ & 1 & 1 & 1 & 1 & 1 & 1 & 1 \\
\hline 5 & $\begin{array}{l}\text { Is the cross-sectional representative of the } \\
\text { defined population? }\end{array}$ & 1 & 1 & 1 & 1 & 1 & 1 & 1 \\
\hline 6 & Was the follow-up done in sufficient time? & 1 & 1 & 1 & 1 & 1 & 1 & 1 \\
\hline 7 & $\begin{array}{l}\text { Are objective and unbiased outcome criteria } \\
\text { used? }\end{array}$ & 1 & 1 & 1 & 1 & 1 & 1 & 1 \\
\hline 8 & $\begin{array}{l}\text { What is the confidence intervention } \\
\text { measurement method provided? }\end{array}$ & o & o & o & $\mathrm{O}$ & $\mathrm{O}$ & o & $\mathrm{o}$ \\
\hline 9 & Are effect sizes practically relevant? & 1 & 1 & 1 & 1 & 1 & 1 & 1 \\
\hline 10 & Is there a belief intervention provided? & 1 & 1 & 1 & 1 & 1 & 1 & 1 \\
\hline 11 & $\begin{array}{l}\text { Have confounding factors been taken into } \\
\text { account? }\end{array}$ & 1 & 1 & 1 & 1 & 1 & 1 & 1 \\
\hline \multirow[t]{2}{*}{12} & Do the results apply to your research? & 1 & 1 & 1 & 1 & 1 & 1 & 1 \\
\hline & Total & 11 & 11 & 11 & 11 & 11 & 11 & 11 \\
\hline
\end{tabular}




\section{DISCUSSION}

1. The relationship between work duration and low back pain

The results of the meta-analysis showed that there was a significant effect between work duration and the risk of low back pain in office workers.

This is in line with Tanzil et al. (2019) which states that low back results of 5 years of service having an increase of 2.89 times more risk of experiencing low back pain than those who work $<5$ years. Other studies have shown that working in front of a computer while sitting causes low back pain.

The longer the working period of a worker, the higher the risk of occupational diseases. Repetitive work activities over a long period of time can burden the same muscles and soft tissues over a long period of time (Susanti, 2015). In this metaanalysis, the risk factor for tenure is the period of time for office employees who work in a workplace, which is calculated from starting work by dividing into 2 groups, tenure $<5$ years and 5 years.

Yang et al. (2017) showed that length of work 40 years increased the risk of low back pain in workers $(\mathrm{OR}=1.19 ; 95 \% \mathrm{CI}=$ 0.99 to 1.43 ).

\section{The relationship between sitting position and low back pain}

The results of the meta-analysis show that there is an effect of working attitude in a sitting position on the risk of employees experiencing low back pain.

Bontrup et al. (2019) stated that there is a relationship between sitting attitude and low back pain. Liira et al. (1996) found that body position affects the magnitude of the load on the lumbar spine, and the magnitude of the load increases significantly when sitting compared to standing upright and lying down with good support.
It has been postulated that persistently awkward sitting postures (lordosis/too arched, or kyphosis/too stooped) can result in higher intradiscal pressures and may compromise spinal postural health (Pynt et al., 2002; Lis et al., 2007; Cho et al., 2015).

Dynamic sitting behavior is considered to have beneficial biological and physiological effects, because postural variations can reduce spinal load and spinal shrinkage, prevent muscle fatigue through alternating motor unit activation, and inhibit damage to the posterior aspect of the annulus pulposus through low-strength dynamic movements (van Deursen et al., 2000; van Dieën et al., 2001; Callaghan and McGill, 2001; Davis and Kotowski, 2014).

Currently, various studies have been developed on the creation of technology to improve more dynamic sitting behavior among office employees (Goossens et al., 2012; Davis and Kotowski, 2014).

\section{AUTHOR CONTRIBUTION}

Herawati Prianggi is the lead researcher who selects topics, searches, and collects research articles. Bhisma Murti and Hanung Prasetya analyzed the data and interpreted the results of the meta-analysis data synthesis.

\section{FUNDING AND SPONSORSHIP}

This study is self-funded.

\section{CONFLICT OF INTEREST}

There is no conflict of interest in this study.

\section{ACKNOWLEDGEMENT}

We thank the providers PubMed, Science Direct, and Google Scholar, who have provided an open access database of article publications. 


\section{REFERENCES}

Adhikari B, Ghimire A, Jha N, Karkee R, Shrestha A, Dhakal R,Niraula A, et al. (2021). Factors associated with low back pain among construction workers in Nepal: A cross-sectional study. PLoS ONE 16(6): e0252564. https://doi.org/10.1371/journal.pone.025256 4 .

Belay MM, Worku A, Gebrie SA, Wamisho BL(2016). Epidemiology of low back pain among nurses working in public hospitals ofAddis Ababa, Ethiopia. East Cent Afr J Surg. 21(1): 113-131. https://doi.org/10.4314/ecajs.v21i1.13 9040.

Bontrup C, Taylor WR, Fliesser M, Visscher R, Green T, Wippert PM, Zemp R (2019).Low back pain and its relationship with sitting behaviour among sedentary office workers. Appl Ergon. 81: 102894.https://doi.org/10.1016/j.apergo.2019.102894.

Callaghan JP,McGill SM (2001). Low back joint loading and kinematics during standing and unsupported sitting. Ergonomics. 44(3): 280-294. https://doi.org/10.1080/001401300100081 10.

Cho IY, Park SY, Park JH, Kim TK, Jung TW, Lee HM (2015). The effect of standing and different sitting positions on lumbar lordosis: Radiographic study of 30 healthy volunteers. Asian Spine J. 9(5): 762-769. https://dx.doi.org/10.4184\%2Fasj.2015.9.5. 762.

Davis KG, Kotowski SE (2014).Postural variability: an effective way to reduce musculoskeletal discomfort in office work. Hum Factors. 56(7):1249-61. https://doi.org/10.1177/00187208145 28003.

Diallo SYK,Mweu MM, Mbuya SO Mwanthi MA (2019). Prevalence and risk factors for low back pain among university teaching staff in Nairobi, Kenya: a cross-sectional study.F10ooRes. 8: 808. https://dx.doi.org/10.12688\%2Ff10ooresearch.19384.1.

Goossens RHM, Netten MP, Van der Doelen B (2012). An office chair to influence the sitting behavior of office workers.Work.41(1):2086-8.https://doi.org/10.3233/wor-2012-0435-2086.

HannaF, Daas RN, El-Shareif TJ, AlMarridi HH, Al-Rojoub ZM, Adegboye OA (2019).The relationship between sedentary behavior, back pain, and psychosocial correlates among university employees. Front Public Health. 7:80. https://doi.org/10.3389/fpubh.2019.00080.

Inoue $\mathrm{G}$, Miyagi M, Uchida $\mathrm{K}$, Ishikawa $\mathrm{T}$, Kamoda H, Eguchi Y, Orita S, et al., (2015). The prevalence and characterristics of low back pain among sitting workers in a Japanese manufacturing company. J Orthop Sci. 20(1):23-30. https://doi.org/10.1007/s00776-0140644-x.

Kawaguchi M, Matsudaira K, Sawada T, Koga $\mathrm{T}$, Ishizuka A, Isomura $\mathrm{T}$, Coggon D (2017). Assessment of potential risk factors for new onset disabling low back pain in Japanese workers: findings from the CUPID (cultural and psychosocial influences on disability) study. BMC Musculoskelet Disord. 18(1): 334. https://doi.org/10.1186/s12891-017-1686-y.

Kurnia R, Adriani RB, Demartoto A (2016). Association between personal and environmental factors, bodyposition on low back pain at Dr. Moewardi Hospital, in Surakarta.J Health Promot Behav. 1(1): 19-25. https://doi.org/10.26911/thejhpb.2016.01.01. 03 . 
Lena V. Kalling, Victoria B, Bjorn E, Tobias H, Jane S, Gunnar A, Peter W, Elin E (2021). Workplace sitting is associated with self reported ganeral health and back/neck pain: a cross-sectional analysis in 44,978 employees. BMC Public Health. 21: 875. http://doi.org/10.1186/s12889-021-10893-8.

Liira JP, Shannon HS, Chambers LW, Haines TA (1996). Long-term back problems and physical work exposures in the 1990 Ontario Health Survey. Am J Public Health. 86(3): 382-7. https://doi.org/10.2105/ajph.86.3.382.

Lis AM,Black KM, Korn $\mathrm{H}$, Nordin $\mathrm{M}$ (2007). Association between sitting and occupational LBP. Eur Spine J. 16(2): 283-298. https://dx.doi.org/10.1007\%2Fso0586-006-0143-7.

Matsudaira K, Konishi H, Miyoshi K, Isomura T, Inuzuka K (2014). Potential risk factors of persistent low back pain developing from mild low back pain in urban Japanese workers.PLoS One. 9(4):e93924.https://doi.org/10$.1371 /$ journal.pone.0093924.

Min S, Ho-Joong K, Hyunseok J, Hyoungmin K, Bong-Soon C, Choon-Ki L, Jin $S$ (2018). Longer sitting time and low physical activity are closely associated with chronic low back pain in population over 50 year of age: a crosssectional study using the sixth Korea National Health and Nurtrition Examination Survey. SPINEE. 529-9430 (18). http//doi.org/10.1016/j.spinee.2018.04.003.

Pynt J, Higgs J, Mackey M (2002). Historical perspective milestones in the evolution of lumbar spinal postural health in seating. Spine (Phila $\mathrm{Pa}$ 1976). 27(19):2180-9. https://doi.org/10.1097/00007632-200210010-00020.
Sameh M, Abolfotouh, Karim M, Khaled F, Gameh M, Abir E, Mostafa A, Abolfotouh A (2015). Prevalence, consequences and predictor of low back pain among nurses in a tertiary care setting. SICOT. 39(12):2439-49. doi: 10.1007/s00264-015-2900-X

Spyropoulos P, Papathanasiou G, Georgoudis G, Chronopoulos E, Koutis H, Koumoutsou F (2007).Prevalence of low back pain in greek public office workers. Pain Physician.10(5):6519.PMID: 17876361.

Sudholz B, Ridgers ND, Mussap A, Bennie J, Timperio A, Salmon J(2018). Reliability and validity of self-reported sitting and breaks from sittingin the workplace.J Sci Med Sport. 21(7):697701.https://doi.org/10.1016/j.jsams.2017.10.030.

Tanzil S, Jamali T, Inam B, Abbas A (2019). Frequency and severity of low back pain among healthcare providers and associated factors in a tertiary care, public hospital in Karachi. Occup Med Health Aff. 7(1): 285. https://doi.org/10.4172/2329-6879.1000285.

Mekonnen TH (2019). Work-related factors associated with low back pain among nurse professionals in East and West Wollega Zones, Western Ethiopia, 2017: A cross-sectional. Pain Ther. 8(2): 239-247. https://doi.org/10.1007/s40122-019-0129-x.

van Deursen DL, Lengsfeld M, Snijders CJ, Evers JJM, Goossens RHM (2000). Mechanical effects of continuous passive motion on the lumbar spine in seating. J Biomech.33(6): 695-699. https://doi.org/10.1016/Soo21-9290(99)oo231-6.

van Dieën JH,De Looze MP, Hermans V (2001). Effects of dynamic office chairs on trunk kinematics, trunk extensor EMG and spinal shrinkage. 
Prianggi et al./ Sitting Position, Working Duration, and Low Back Pain

Ergonomics. 44(7): 739-750. https://doi.org/10.1080/00140130120297.

Xu CX, Zhu HH, Fang L, Hu RY, Wang H, Liang MB, Zhang J, Lu F, et al. (2017). Gender disparity in the associations of overweight/obesity with occupational activity, transport to/from work, leisure-time physical activity, and leisure-time spent sitting in working adults: A cross-sectional study. $\mathrm{J}$ of
Epidemiol. 27(9):401-407. http://dx.doi.org/10.1016/j.je.2016.08.019.

Yang H, Haldeman S, Lu ML, Baker D (2016).Low back pain prevalence and related workplace psychosocial risk factors: A study using data from the 2010 National Health Interview Survey. J Manipulative Physiol Ther. 39(7): 459-472. https://dx.doi.org/10.1016\%2Fj.jmpt.2016.07.004. 